脳疾患時 (とくに脳外科手術後)に生ずる上部消化管出血に 対する開腹手術の適応と手術方針について

\author{
神亚火学医学部第 1 外科 \\ 堀公行 西村和夫 光野 孝雄
}

\title{
SURGICAL MANAGEMENT AND ITS PROCEDURE OF THE MASSIVE GASTRO- INTESTINAL HEMORRHAGE COMPLICATED AFTER NEUROSURGERY
}

\author{
Kimiyuki HORI, Kazuo NISHIMURA and Takao MITSUNO \\ The 1st Department of Surgery, Kobe University School of Medicine
}

\begin{abstract}
脳疾患時，とくに脳外科手術後に生ずる出血性ストレス潰㹲例は，ほとんど意識障害な有し，その原抦

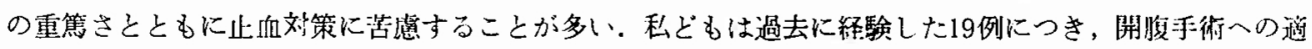
応時期を検討し，さらにその胃手術法につき述べる。

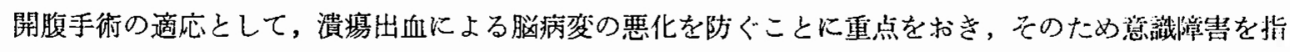

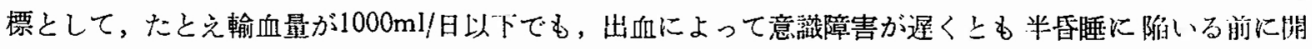
腹手術を行らべきである。この祭手術法として溃瘍病変の広がりと, 胃切後もまだなおつつくとみられる ストレスによる残胃十二指腸の再出血を抑制することなどから，小弯を多く切除する画全摘に近い六籁型 切除術に幹迷切術を併施することが最良であると強調した。
\end{abstract}

索引用語 : ストレス潰瑏, クッシング潰瘦, 消化管出血, 迷切術

\section{I はじめに}

中枢性脳疾患と胃十二指腸潰瘍の関連について, 古く Rokitansky1) の剖検報告例，さらに Cushing ${ }^{2)} の$ 視床下 部の影響による neurogenic ulcerとしての示唆以来, そ の潰瘍成因についての研究は枚举に遈がない、しかし臨 床面での頭蓋内疾患時や殊に脳手術後に生ずる消化管出 㨫は，情動的ストレスによる急性潰瘍や慢性潰瘍の再 発・再然によるものと異なり，その背景に脳疾患とそれ に附随した全身状態の悪化といら因子があるため, 消 化管出血に対する治療の選択には困難を感ずることが多 い.しかもこの消化管出血が始まる際には，すでに原病 の脳疾患が重篤なるのとなっているか，これを契機に重 篤となる場合が多く，開腹手術の決定を遜らせる原因と もなっている。

そこで本稿では，私と゚もが過去に経験した頭蓋内疾患 患者の脳手術前後に発生した上部消化管出血の症例につ いて, 保存的療法や開腹手術の適応と時期を検討考察
しそそれらに基づいて現在私どもが行っている治療方針 について述べる.

\section{II 臨床例の検討}

1. 症例の内容 (表 1).

私どもが経験した症例は, 脳腫瘍 9 例, 脳動脈瘤 5 例, 頭蓋内血腫 5 例の計19例であるが, 開頭術前に吐下 血を来たした症例は 2 例で，他の17例は開頭術後に出血 して当科へ転科, 治療されたものである.この頭蓋内将 患の種類と胃腸管出血とには著明な相関を認めなかった が, 強いていえば，脳幹部へ容易に影響を及ぼし易い部 位に病変が存在していたといえる。

\section{2. 治療成績 (図 1).}

開腹手術へ踏みきった症例と保存的療法を行った症例 はそれぞれ10例と9例ではほ济同数であった．その予後 をみると，前者の手術例のうち軽快例は 7 例 $(70.0 \%)$ ， 後者の軽快例は 3 例 $(33.3 \%)$ で，開腹手術を行ったも のが予後良好であったといえる，しかし能者には1力月 
表 1 中枢性溃瘳出血の臨床例

\begin{tabular}{|c|c|}
\hline A) & 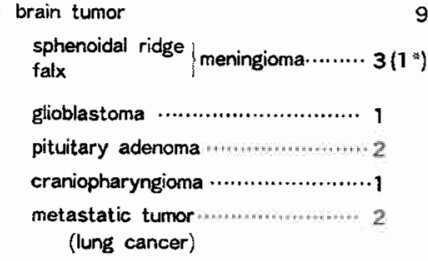 \\
\hline B) & 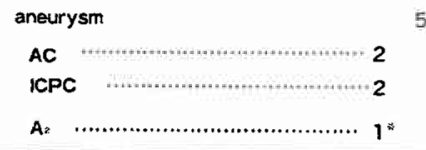 \\
\hline C & 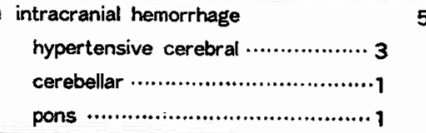 \\
\hline
\end{tabular}

* before operation

因1 中枢性潰瘍の消化管出血の治療成續

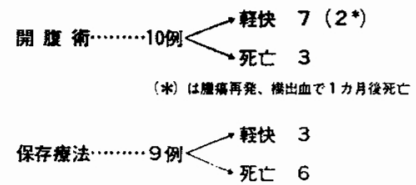

前後で腫焬再発による脳へルニヤと, 橋出血による笑然 死の 2 例があるが，これらの経過は，開腹手術の影響が 一応去った時期の 1 カ月後に死亡して扣り, 手術効果は あったものと考えられた。

3. 消化管出血発現期 (図 2 ).

開酤術前に吐下向を来たした 2 例を除き, 開頭術後の 17拉例については，雮手術から吐下血を呈するまでの期 間は平均5.4日であった。その内容をみると，開腹手術 を行って軽快したものは4.6日，死亡したものは1.5日， 保存的に 治療したものの軽快例は 11.6 日後, 死亡例は 4.2日でもった。単に発症期間のみをみると, 術後短期 間に発街したものは予後が悪く，10日以上のものはよい とい方た。

図 2 開頭術後より消化管出血までの日数（17症例 について)

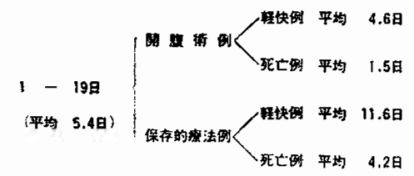

4. 輸血量 (出血量) と治療期間.

各症例の出血量の程度を輸血量で代用して検討した. まず開腹手術を行った症例（表 2）についてみると，

表 2 消化管出血より開腹手術までの輸血量と待期 時間

\begin{tabular}{|c|c|c|c|c|}
\hline 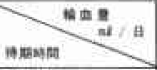 & $<600$ & $600-1000$ & $1600-2000$ & $>2000$ \\
\hline-12 新闻 & & (1) & (1) & 1 \\
\hline $12-24$ 的数 & & & 1 & (1) \\
\hline-3 日 & & 2 & & \\
\hline 一7日 & 1 & & & \\
\hline $10 \mathrm{~B}$ & 1 & & & \\
\hline 19 日 & 1 & & & \\
\hline
\end{tabular}

$600 \mathrm{ml} /$ 日以上の輸血を必要としたものは 3 日以内に手術 されて呿り，7例中 4 例が軽快し，3例が死亡した。こ の死亡例はともに24時間以内に手術された症例であった が，他方同じ24時間以内手術例で 2 例が $1600 \mathrm{ml} /$ 日以上 の輸血量を必要とする大量出血例でありながら軽快して いるので, 大量出血即緊急手術の図式で必らずしも予後 の明暗を論ずることはできなかった。 $600 \mathrm{ml} /$ 日以下の輸 血量のものは, 出血開始から 7 日〜19日後に開腹手術を 受けて軽快しており, 充分な待期期間を有した症例であ った.

次に, 保存的療法を行った症例（表 3）について調べ た.とのなかに 1 例の吐下血を来たして輸血する間もな く死亡した症例があるが，これは潰瘍病変の悪化よりも 脳死が先行したので, 保存的療法例に入れて検討すべき 症例ではなかったかむしれない，しかし後述する治療適 応の 1 つの指標として, 脳病変について考党る必要性か らここに加えた。この他の 8 例のうち，3例が軽快した

表 3 保存療法例一 1 日輸血量と輸血日数一

\begin{tabular}{|c|c|c|c|}
\hline 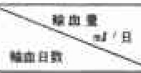 & $<400$ & $400-600$ & $601-1000$ \\
\hline$\theta$ & (1) $\times$ 勫 & & \\
\hline 1 & 1 & (1) $\times 3$ 日 & \\
\hline 3 & $2 \int_{(1) \times 6 a}^{1}$ & & \\
\hline 6 & 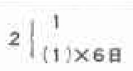 & & \\
\hline 10 & & & (1) $\times 13 \mathrm{~B}$ \\
\hline
\end{tabular}


が，この 3 例は開頭術後平均11.6日で出血したもので， $400 \mathrm{ml} /$ 日以下の輸血をそれぞれ $1 ， 3 ， 6$ 日間行い，全 身状態が非常によく保たれたものであった，死亡例は $400 \mathrm{ml} /$ 日前後から $1000 \mathrm{ml} /$ 日までの輸血を主とした保存 的療法を，吐下血開始より3日から最長19日間にわたり 行われた。このうちには，保存的療法により止血を期待 しているらち状態を悪化させたものと，脳病変が悪化し て既にその改善がみられないため，消化管出血の治療を 断念したものとの 2 通りがあった。

5. 吐下血と故病変, とくにその治療前後の意識障害 について

消化管出血を呈するストレスとなった原病の脳病変程 度を知るため, 各症例飞ついて意識障害の推移を調べ, その治療効果との関連を検討した。

消化管出血時の意識障害度は清明から昏睡までと種々 にみられた（园 $3 \mathbf{a}, \mathbf{b})$. そのちちの開腹術症例について みると（図 3a)，開腹手術が行われた時期は，軽快例で 全例遅くとも半昏睡になる直前であった。死亡 3 例のう ち2 例は, 昏睡時に手術がなされ，1例は譫妄時に行わ れた。保存的療法例（図 $3 \mathbf{b}$ ) のうち, 軽地例は脳病変 の程度が軽く, 嗜眼以下で終始し, 自力で止血したもの であった. 死亡 6 例については，そのらちの3 例が吐下 血時, すでに半昏睡から昏睡に陥っていたるのである. 他の 3 例は消化管出血時㖺眠状態であったが，保存的療 法続行中に意識状態が昏睡へ陷こみ死亡した。

したがって開腹手術は遅くとも半昏睡になる前の昏迷 時までに施行されるべきと考兄られ，昏睡時では予後が 極めて悪くなるといえる。しかし非開腹例では，軽快 3 例が搘眠より良好な状態で終始したものであり，死亡例 はそれよりむ保存的治療経過ととすに次第に悪化したる のである.すなわち出血の発症とその進展状況を知るう

因 3 中枢性潰㙏出血前後の意識障害の程度

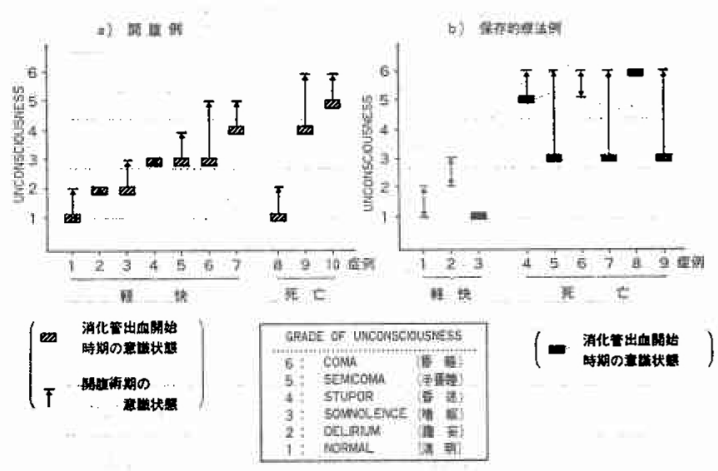

因 4 中枢神経疾患時の潰癔病変部位

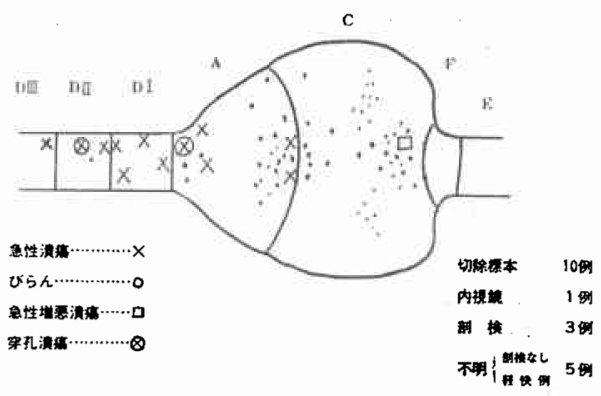

えに，意識障害の推移を知ることは極めて重要で，この ことは治療法の選択に必要であると考えられた。

6. 潰瘍病変部 (図 7).

保存的療法で軽快した症例，ならびに死亡したが剖検 できなかった例を除いて，胃切除10例，剖検 3 例，内視 鏡 1 例の計14例について胃の病変を調べた。ここで，漬 瘍とびらん上は閣一カテゴリ一で発生したと考党，一粎

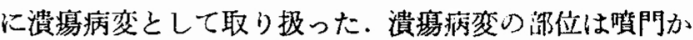
ら十二指腸の第 3 部位にいたるまで広笔にあり，胃では 胃角部に集中することすなかった。とくにびらんの発生 部位は胃街部に多くあるようにみられたが，体部や前庭 部にもすなわち胃全般にわたっていた。しかし十二指晹

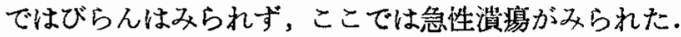

潰瘍の内容は消化性潰瘍の急性潰瘍を混在したもの， 多発びらんのみのもの，胃びらんと十二指腸潰潢など各 種潰瘍病変の多発混在したものが汪とんどであった。

7. 各種薬片の使用.

頭蓋内疾患は气の治療中，消化管飞潰疡病变を発症さ せ易いステロイドホルモン，レセルピンや下熱珮を用い ることがある。私どもの症例についても，出血が現れる まで用いられた薬剤を調べた、ステロイドは8例（50.0 $\%$ ）に，レセルピンは2 例 $(10.5 \%)$ 飞投与されてい た. その他アスピリン、インダシン系下熱剤が随時使用 されていた．しかしこれら使用薬凧と消化管出血との関 連は，投与期間，投与量，開頭術前中後等一定傾向はみ られず，その関係を明らかに指摘することはできなかっ た.

\section{III 考 察}

1）術後出血珄潰湟に対する手術適応基淮の必要性.

消化性潰瘍の出血例之異なり，外科手術後や火傷など ストレス潰瘍の出血症例はいまだに予後は悪い(3). 私 ぞすの教室でむ中枢性潰瘍や一般腹部外科手術などを含 めた術後のストレス潰瘍出血例の死亡率は $47.2 \%$ と極め 
て悪い゙．本稿で述べている脳疾患時に限った症例での 死亡率は19例中 9 例 $47.4 \%$ であた。このうち保存的療 法を行ったとさの死亡率 $66.7 \%$ より積極的な外科治療で ある開腹胃切除例のそれ30.0\%が予後良好であった。乙 かしこのような場合，手術成績がよいから積極的闰開腹

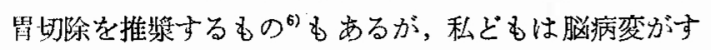
でに終末期にあるたら, 開腹手術適応の判断より脳病変 改善の必要性が先行する症例をも経験している. したが って該当症例が開腹手術によって救命されるものである のか, また努力を行ってもいわゆる脳死への進行をくい とめられないるのであるのか, それを手術前に的確に判 断することが治療成績の向上結びつくと思われ，その 適応基準となる条件を考察する必要があると考学られ た。

2）頭盖内疾患患者の潰湯発症について.

一般に頭蓋内疾患時の胃腸管出血をきた寸時期は，開 頭術後 7 １0日前後とするすのが多( ${ }^{6)}$-101. 私どもの 症例でも平均 5.4 日後で発症しているが, 脳病変の重症: 例は早く，軽症例は遅く発症しているようであった。

このような脳疾患には, 浿愓をひき起こさせる薬剤が 多種优われることはやむをえないことであるうが，私ど もの鿊例ではステロイドが50.0\%に使われていた。荒 木 ${ }^{11)}$ はステロイド投与群と非投与群で出血発症に差異は 見出させなかったといっている：しかしステロイドによ る粘膜防御因子の 減退 ${ }^{12)}$ とさらに加わる中枢刺激によ

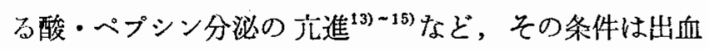
性溃瘍が非常に発症し易い状態となっていると考光られ る。また高血生脳出血の際使用される Rauwolfia alk-

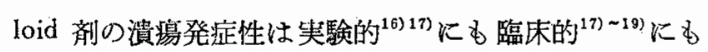
いわれることであり，また中枢性過高熱に対する下熱剤 など, 頭蓋内疾患患者へのこの種薬剂投与は慎重飞行わ 礼る必要がある。

3）外科治療の適応.

開頭術後や脳腫場などで消化管出血をきたすすのに は，すでに重篤なるのが多いと荒木 ${ }^{111}$ は述へててる. 私どもの症例でも開頭術後平均1.5日後飞出血した 3 例 は，24時間以内の開腹術でる救命しきれなかった。この らち 2 例は, 手術時すでに意識障害の程度が覀く, 脳狱 変の進行度は終末期に近い状態であった. しかし他の 1 例は，正常に近い意識状態でありながら死亡した。これ は十二指晹の第 2 第 3 部位での潰煌からの出血が主と なって怙り，このような部位の出血に対する止血法が今 後検討されなけれぱならない問題として残された。
さて出血量の点から開腹術症例の予後を検討すると， 死亡例は $600 \mathrm{ml} / 12$ 時間以上と $1600 \mathrm{ml} / 24$ 時間以上の 輸血 を必要としており，しかも12〜24時間以内に手術され た.この点よりみれば,これらの症例は短時間内に極め て大量に出血したものとい方る。しい表 2 の招り， $1600 \mathrm{ml} / 12$ 時間以上の輸血を必要とした症例でも，24時 間以内に手術された患者の 2 例は救命されているので, 必ずしも出血量や早急な手術施行が予後を左右する条件 になるとは考えられない，一般に消化性潰瘍に拮する出 血例は1000 $\mathrm{ml}$ の翰血を行っても改善しない場合, 㗨急

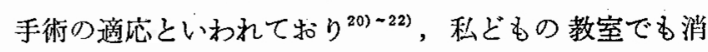
化性潰瘍の出血例飞対してはこの基準で手術を行ってい る.しかし中权性潰瘍からの出血症例の場合には，上記 の上うな出血量のみから手術適応を考学るわけにはいか

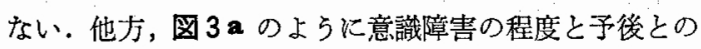
関係をみると，開腹術後生存例はいずれる昏迷より良好 であり，少なくとも半昏睡に達する前に外科処置がなさ れていた．したがって術後の予後を知るら六に出血量は むちろん大切で西るが，出血をひき起こした原病の状態 をよく把握することがより大切であるとい竞る。

一方保存的療法を行った症例をみると，軽快したもの は出血開始が開頭術より平均11.6日後であり出血量は $400 \mathrm{ml}$ 以下の輸血で全身状態が拜さまったことより， 出血程度が非常に軽いものであり,しかも意識障害は㪘 眠以下といら良好な脳神経状態であった。ところが死亡 6 例についてみると, 出血まで平均 4.2 日と短かく，乙 か子輸血量は輸血が間にあかなかった 1 例を除いて400 〜1000 ml/日にわたり，その治療期間が 死亡まで $3 \sim 13$ 日と種々であった。また意識障害は半昏睡から皆睡まで が3例あり，そして赀眠のときに始まり，治療経過中に 型化して昏睡に陷ったるのが 3 例あった。すなわちこの 場合の治療方針に 2 つことが考学られる１つは脳病 変の䔡化が急で開腹手術が 因難と考兄られたるのであ り，他の 1 つは，なんとか保存的療法で止血を試みよう としているらち, 断続的に続いた消化管出血によって脳 病変を悪化させてしまったものである．結果的に，開腹 症例よりみた治療成績からみると, 前者は手術を強行し ても成功しなかったかもしれないが，後者は待機するこ となく開腹手術へ踏みさるべきであったのではないかと 考えられた。

以上のことを⿱とめて開腹手術の適応特にとの時期に ついて考觉ると，その最も要点となるとこうは，出血の 補正に要した輸血量が $1000 \mathrm{ml} /$ 日以上といら量にこだ 
ることなく，たとえば400〜 $600 \mathrm{ml} /$ 日であっても意識障 害が出血によって悪化しつつあるときにはるちろん早急 に手術すべきであるが，遅くとも意識障害が半昏睡にな るまえの昏迷時までに手術を決定し行われるべきである とい光るこの適応恃開頭衍前症例についても市てはま るといえた。

4）上述の手術適応基準にあわない死亡症例につい $\tau$.

前項では意識障害の程度を手術適応の最重要因子とし て考察したが，ひるがえって私どもの症例で出血時意識 障害が昏迷か，あるいはそれよりる良好な状態であった にもかかわらずその後死亡した症例についてその原因を 検討した（表 4 ). 開腹手術施行の 2 例は, 出血性十二指

表 4 出血㭙, 替迷以下 $(4 \leftrightarrow 1)$ 症例における死 亡例の検討

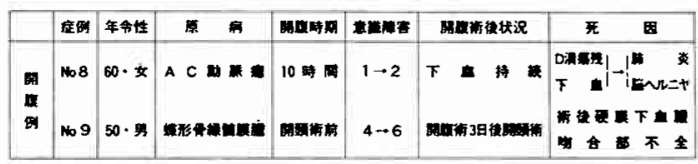

\begin{tabular}{|c|c|c|c|c|c|c|c|c|}
\hline & 整国 & 年命姝 & 苗 & 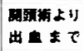 & $\begin{array}{l}\text { 出より } \\
\text { 无亡まで }\end{array}$ & 害 & 西亡まての治机 & 弄 因 \\
\hline $\begin{array}{l}\text { 保 } \\
\text { 年 }\end{array}$ & No 5 & $71 \cdot$ 女 & 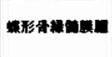 & 5 日 & 6日 & $3 \rightarrow 6$ & m $4800 \mathrm{ml} / 6$ 日 & 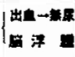 \\
\hline 的 & No 7 & $5 t$ - 男 & 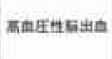 & 4日 & 198 & $3 \rightarrow 6$ & $\begin{array}{r}\text { 血 } 1830 \text { ms } / 6 \text { 日 } \\
\text { (断䐜的) }\end{array}$ & 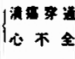 \\
\hline 洷 & No 9 & 44. 男 & 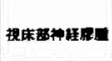 & 6 日 & 119 & $3 \rightarrow 6$ & 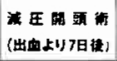 & 出出 \\
\hline
\end{tabular}

晹潰瘍遗残之術後硬膜下血腫ならびに吻合部縫合不全の 合併により死亡し，このうち前者は3)の項で既述した症 例である。また後者は開腹時点で昏睡状態に陥っていた ものであった，一方保存的療法例では，断続した消化管 出血, さらに潰場穿通に上る全身状態の悪化が㖺眠から 昏睡に陥らせたものであった。つまりこれらの原因には 開腹手術操作に起因したものと, 保存的療法の長期化に よって手術時機を失したことによるるのとがあるといえ た.

5）手術方法の検封.

このようなストレス潰瘍に，かつて Sullivan ら ${ }^{23)} は$ 迷切術を推奨した。しかしその後彼ら自身14\%に再発出

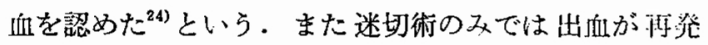

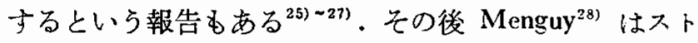
レス潰湯出血に対する治潦方針として,リスクが覀い汪 どその治療はより根治的なものにすべきで市ることを述 ベ, near total gastrectomy がよいと述べた。私どもも出
血している胃を広範に切除することが最も確実な治療法 であり，外科治療の主要操作でなければならないと考え ている.

このような観点にたてば，次に出血港愓の発生部位が 問題になる。従来ストレス潰癔は胃体部に多く発生する

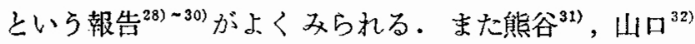
によると，高血压性脳出血飞括汁る病変は，胃街部を中 心とした胃体部，胃前庭部の全般汇生ずるといら。また Cushing ulcer は食道上り上部小䁑にわたって広範囲に 生ずるともいわれる ${ }^{33)}$ ．しかし脳疾患で消化管出血をき たすような症例は，重症例が多くてステロイドその他種

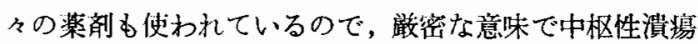
い特長的な発症形態と発生部位を述べることは困難と思

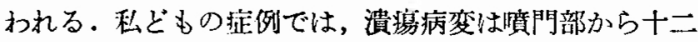
指腸上行脚にまでみられ，その理度も多発出血斑，びら ん，急性潰愓，ささらに慢性潰愓の急性增悪など，その態 橡は一様でなく，なかにはすべての種類の潰湯病変を包 含するものむあった．しかし潰瘍病変の最る秱密部位は 小弯側，すなわち胃街に沿ってあり，潰瘍病変はこの部 位にかなり集中していた。

したがって以上のことを考光，私どもは噴閒に近い小 弯側をより多くとるように滈位置に胃切除線を㧍き，消

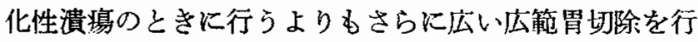
っている.この切除線は Menguy ${ }^{28)}$ が示した near total gastrectomy よりも大弯側をより大きく残して抢り，手 技的にも大ベッッを使って, 早く容易に手術を進めるこ とができる.

胃切除が終ると，私どもは幹迷切術をそれに付加して いる. その根拠とするところは, 前述の通り潰瘍病変の 分布状態からいって，広範胃切除です切除し尽せない病 変が残る可能性が大きく，そして遗残した病変に対し て，多少効果が㘯るだろうと思われる迷切術で止血を図 るということにある。さらに脳疾患患者は出血時期前後 といわず，開腹手術後でもストレス状態が持続して迷走 䦿経緊張状態から脱することが長びくものと考兄られ， そのため胃切除後の残胃に出血性潰燩が再発する可能性 も考学られないことではないので，迷㥸術はその予防に もなると考㝋られる、すなわち，迷切術は消化管特に胃 组流の減少をきたし ${ }^{34)}$ ，その現象に伴うであらう残存消 化管での出血発症の抑制効果を期待するわけである.

この術式については，著者の 1 人光野ら ${ }^{35)}$ がすでに報 告しているが, かつて教室の伊藤ら ${ }^{36)}$ がこの手術法を学 会で報告した際，このような状熊の覀い患者に over sur・ 
gery ではないかという反論もあった。しかし私どもの 施設では, 脳疾患患者術後のみでなく他の術後ストレス 出血濥瑝でも，この手術自身が直接死亡原因となった 症例はなく、Menguy" ${ }^{28)}$ のいらょうに“The worse the risk, the more radical the procedure.”が最も確実な治 療法として考兄ている. として開腹手術後もひき続いて 胃出血が济れば，患者の全身状態は加速度的飞急速に悪 化するので, 開腹手術は 1 回で完全止血が得られるよう 微底して行われるべきである。しかし胃全摘は手術侵襲 が大き過ぎるので，亜全摘に近い私どもが述べた胃広範 切除兼幹迷切術が最良の手術之考光る. 現在この上うな ストレス潰揞に対し，私どもと類似の手術法を行うとい

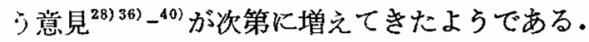

\section{IV まとめ}

頭蓋内疾患患者の之くに開頭術後例に生ずるストレス 演揬出血に対し，開腹手術の適応を中心とし，さらにそ り手術法について述べた：そして開腹手術の嫡応は次の ようにまとめることができた。

1）治療方針は，とくに意識障害程度学中心とし，そ れに出血量之，開頭術後であればそれより消化管出血登 症日までの期間の3つをにらみあわせて考方る。2)保存 的療法の対象例は, 開頭術後例では術後10日以降の出血 発症, そして出血量は $400 \mathrm{~m} /$ 日以下で，とくに意識状態 は嗼眠より悪化しないもの．3）外科療法の対象例は, 開頭術後例では術後 1 週以内の発症が多かった. 出血量 が400 600 $\mathrm{ml} /$ 日以上の翰血を必要とするか，さらに增 加するるのは外科㿟法の対象となるが, 最も肝要なの は，意識障害が正常から昏迷までの間で一定状態を維持 しながら止血しないものはもちろん，消化管出血によっ て意識障害が覀化しつつあるるのは，遅くとも半昏睡に なる前に早急に開腹手術を行うべさである４）意識障 青が消化管出血時点で半昏睡より悪化し，またすでに皆 睡に陥っているものは脳病变の治潦がより先行し, 開腹 于術の適応とはなり難い。

以上の党応から開腹手術を行ら場合の手術方法は，小 苮をできるだけ高位で切除する広範胃切除術と，幹迷切 術の併施は最良の手術方法であると強調した。

本論文の要旨は第 7 回日本消化器外科学会大会 (鹿児 島に打いて発表した。

\section{文 献}

1) Rokitansky, C.: Cited by Palmer, E.D.: Upper gastrointestinal hemorrhage. p. 148, C.C. Thomas Publisher, 1970.
2) Cushing, H.: Peptic ulcers and the interbrain. Surg. Gynec. Obst., 55: 1-34, 1932.

3) Fogelman, M.J. and Garvey, J.M.: Acute gastroduodenal ulceration incident to surgery and disease. Analysis and review of eighty eight cases. Am. J. Surg., 112: 651-656, 1966.

4) 島津久明, 他 : 重䉆疾患, 外科手術などに続発 した胃・十二指腸の急性溃愓性病変。臨外, 28, 1215-1221, 1973.

5) Hori, K. et al.: Surgical management of stress ulcer complicated after surgical operations. International College of Surgeons, 2nd Congress of the Asian \& Pacific Federation. 15: Dec., 1977, Atami, Japan.

6) 古瀬消次, 他 : 開頭術後の大量消化管出血に対 する外科的適応. 手術, 26, 1151-1155, 1972.

7) French, J.D. et al.: Gastrointestinal hemorrhage and ulceration associated with intracranial lesions. A clinical and experimental study. Surgery, 32: 395-407, 1952.

8) Davis, R.A. et al.: Acute upper alimentary tract ulceration and hemorrhage following neurosurgical operations. Surg. Gynec. Obst., 100: 51-58, 1955.

9) Beil, A.R. et al.: Massive upper gastrointestinal hemorrhage after operation. Am. J. Surg., 108: 324-330, 1964.

10）金谷春之, 他 : 急性脳障害之胃晹病変. 外科垓 療, 16, 1198--2204, 1974.

11) 荒木五郎：脳嗹瘍と胃腸出血。日消会誌，69, 721-725, 1972 .

12) Menguy, R. and Master, Y.F.: Effect of cortison on mucoprotein secretion by the gastric antrum of dogs pathogenesis: of steroid ulcer. Surgery, 54: 19-28, 1963.

13) Porter, R.W. et al.: Hypothalamic influences on hydrochloric acid secretion of the stomach. Surgery, 33: 875-880, 1953.

14) Idjadi, F. et al.: Prospective study of gastric secretion in stressed patients with intracranial injury. J. Trauma, 11: 681-688, 1971.

15) Gordon, M.J. et al.: Divergent nature of gastric mucosal permeability and gastric acid secretion in sick patients with general surgical and neurosurgical disease. Ann. Surg., 178: 285-294, 1973.

16) Blackman, J.G. and Campion, D.S.: Mechanism of action of reserpine in producing gastric hemorrhage and erosion in the mouse. Brit. J. Pharmacol., 14: 112-116, 1959.

17) Garattini, S. and Valzelli, L.: Serotonin. Elsevier Publishing Company. Amsterdam. London. N.Y., 1965. 
18) Wofford, J.D.: Hemorrhage from duodenal ulcer during the administration of reserpine. New Engl. J. Med., 255: 1193-1194, 1956.

19) Hollister, L.E.: Hematoemesis and melena complicating treatment with Rauwolfia Alkaloid. Arch. Int. Med., 99: 218-221, 1957.

20)松木 久, 武藤輝一：上部消化管大量出血の 手術をめぐる問題点. 臨外., 32, 987-992, 1977.

21）福嶋博愛，他：胃・十二指腸潰榢に和ける緊急 手術症例の検討. 外科診療, 18, 264-268, 1976.

22) 長尾房大, 他 : 外科からみた上部消化管出血. 胃之腸，4，145-151，1969.

23) Sullivan, R.C. et al.: Surgical management of hemorrhagic gastritis by vagotomy and pyloroplasty. Ann. Surg., 159 : 554-562, 1964.

24) Sullivan, R.C. and Waddell, W.R.: Accumulated experience with vagotomy and pyloroplasty for surgical control of hemorrhagic gastritis. Am. J. Surg., 116: 745$750,1968$.

25) Kirtley, J.A. et al.: The surgical management of stress ulcers. Ann. Surg., 169: $801-809$, 1969.

26) Oslen, W.R. et al.: Vagotomy, gastric blood flow and hemorrhage from gastritis. Am. J. Surg., 119: 183-189, 1970.

27) Menguy, $R$. et al.: The surgical management of acute gastric mucosal bleeding. Arch. Surg., 99: 198-205, 1969.

28) Menguy, R.: Surgery of peptic ulcer. W.B. Saunders Company, Philadelphia. London. Toronto, 1976.
29) 大井実,山口吉康 : VI濱劰. 現代外科学大系, 35 A , pp. 257-458，中山湿店， 1970 .

30）頁川暢一，他：ストレスに方る胃粘膜出血の内 視鏡，病理ならびに治療。胃と腸，6，1603一 $1610,1971$.

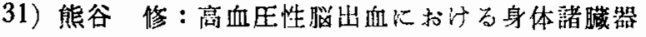
の病理学的变化.日外宝., 34, 651-668, 1965.

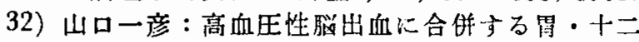
指腸病変に関する臨休病理学的研究一特儿成 因的因子の解析を中心として一。脳と神.，25， 1567--1581, 1973.

33) Palmer, E.D.: Upper gastrointestinal hemorrhage. C.C. Thomas Publisher, Springfield. Illinois, 1970.

34) 田中親彦，他：胃迷切各街式における胃粘膜血 流および胃酸分泌について。第 6 回迷切研究 会，日消外会誌，10，794-795，1977。

35）光野孝婎，三浦順郎：術後消化管出血儿対する 胃手術. 手術, 27，178-186，1973.

36) 伊藤 悟, 他: 診断困難な消化管出血の対策。 術後上部消化管出血の治療(ラウンドテーブル デスカッション). 講演，第 4 回日本消化器外 科大会, 秋田, 1974 .

37) Crawford. F.A. et al.: The stress ulcer syndrome. A clinical and pathologgic review. Am. J. Surg., 121 : 644—649, 1971.

38）武藤輝一：ストレス潰澺の概念と治療方針一外 科の立場から一。踾外., 31，995-1000，1976.

39) Matsumoto, T.: Current management of acute gastrointestinal hemorrhage. C.C. Thomas Publisher, Springfield. Illinois, 1977.

40) 佐藤 博, 他：日米の消化性溃境の現況を語る -L.M. Nyhus 先生を囲んで一。外科診療, 19， 1052-1060, 1977. 